\title{
Caracterização física de Cateteres Centrais de Inserção Periférica (CCIP)
}

\author{
Physical characterization of \\ Peripherally-Inserted Central \\ Catheters (PICC)
}

\author{
Fabiana Cristina Rosa Mitelmão ${ }^{1}$, Salvador Mangini Filho ${ }^{1}$, \\ Marco Vinícius Chaud ${ }^{2}$, Marta Maria Duarte Carvalho Vila ${ }^{3}$, \\ Victor Manuel Cardoso Figueiredo Balcão ${ }^{3,4}$, \\ José Martins de Oliveira Junior ${ }^{1}$,
}

\author{
${ }^{1}$ LaFINAU - Laboratory of Applied Nuclear Physics of the University of Sorocaba, University of Sorocaba, 18023-000 \\ Sorocaba, SP, Brazil. \\ ${ }^{2}$ LaBNUS - Laboratory of Biomaterials and Nanotechnology of the University of Sorocaba, Technological Park of Soro- \\ caba, 18078-005, Sorocaba, SP, Brazil. \\ ${ }^{3}$ PhageLab - Laboratory of Biofilms and Bacteriophages of the University of Sorocaba, University of Sorocaba, 18023- \\ 000, Sorocaba, SP, Brazil. \\ ${ }^{4}$ Department of Biology and CESAM, University of Aveiro, Campus Universitário de Santiago, P-3810-193, Aveiro, \\ Aveiro, Portugal. \\ e-mail: fmitelmao@ivasculardobrasil.com.br, salvador.mangini@prof.uniso.br,jose.oliveira@prof.uniso.br, mar- \\ co.chaud@prof.uniso.br, marta.vila@prof.uniso.br, victor.balcao@prof.uniso.br, victor.balcao@ua.pt
}

\section{RESUMO}

Cateteres centrais de inserção periférica (CCIP) são amplamente utilizados em neonatos internados em Unidades de Terapia Intensiva Neonatal (UTIN). O objetivo do presente estudo foi avaliar as características físicas de CCIP, por meio da aplicação das normas ABNT NBR ISO 10555-1: 2003 e ABNT NBR ISO 105553: 2003, e comparar os resultados produzidos na análise de CCIP no início de seu processo de produção (somente catéteres extrusados) com os obtidos na análise do produto acabado. Testes experimentais foram realizados em CCIP fabricados por um fabricante nacional entre os anos de 2011 e 2012. Os dados foram coletados a partir de testes realizados em ambos os catéteres que foram apenas extrusados, ou seja, sem pintar as demarcações, cortes e outros processos relacionados com garantia de qualidade, e catéteres após a conclusão do processo geral de fabricação. No presente estudo, incluiram-se todos os estágios do processo de produção do catéter que podem gerar algum tipo de modificação no produto que poderia gerar riscos aos pacientes que necessitam utilizá-los. Os catéteres foram analisados quanto à resistência à ruptura, radiopacidade, características de fluxo, vazamento de fluido sob pressão e ocorrência de vazamento de ar na montagem do tubo de sucção, conforme preconizado pelas normas NBR ISO 10555-1: 2003 e NBR ISO 10555-3: 2003. Os resultados obtidos foram satisfatórios em todas as análises realizadas, com exceção da resistência à ruptura, que não atendeu às especificações preconizadas pelos padrões para catéteres de silicone. Examinaram-se também catéteres feitos de poliuretano, que por sua vez cumpriram os padrões no que diz respeito à resistência à ruptura. Como as normas não especificam pontos importantes a serem levados em conta para a realização de testes inequivocamente, foram feitas sugestões para a revisão dessas normas.

Palavras-chave: Teste mecânico. Teste de tensão. Refletividade de raios X. Deformação. Propriedades elásticas. Polímeros.

\section{ABSTRACT}

Peripherally-inserted central catheters (PICC) are widely used in neonates hospitalized in Neonatal Intensive Care Units (NICU). The aim of the study entertained herein was to evaluate the physical characteristics of PICC, through application of the standards ABNT NBR ISO 10555-1:2003 and ABNT NBR ISO 105553:2003, and compare the results produced in the analysis of PICC at the beginning of their production process (extruded catheters only) with those obtained in the analysis of the finished product. Experimental tests were 
performed in PICC manufactured by a domestic manufacturer between the years 2011 and 2012. The data was gathered from tests performed on both catheters that were just extruded, i.e. without painting the demarcations, cutting and other processes related with quality assurance, and on catheters after completion of the overall manufacturing process. In the present study, one included all stages of the catheter production process that can generate some type of modification in the product that could impart risks to the patients needing to use them. The catheters were analyzed for strength to rupture, radiopacity, flow characteristics, leakage of fluid under pressure, and occurrence of air leak in the suction tube assembly, as advocated by the NBR ISO 10555-1:2003 and NBR ISO 10555-3:2003 standards. The results obtained were satisfactory in all analyses performed, except for the resistance to rupture, which did not meet the specifications advocated by the standards for catheters made of silicone. One has also examined catheters made of polyurethane, which in turn did meet the standards with regard to resistance to rupture. As standards do not specify important points to be taken into account for conducting tests unequivocally, suggestions were made for revision of those standards.

Keywords: Mechanical testing. Tension test. X-ray reflectivity. Deformation. Elastic properties. Polymers.

\section{INTRODUCTION}

The Peripherally-Inserted Central Catheter (PICC) [1] was described for the first time in the scientific literature in 1929, as an alternative to access peripherally the central blood venous system, when the german medical doctor Forssmann catheterized himself with a urethral probe through a vein in the cubital fossa. Due to the precarious nature of the materials, the procedure was not implemented at the time. In the 1970's the silicone catheter was developed, being initially utilized in the neonatal intensive care units, but it was after the 1980 's that its use suffered an expansion.

In Brazil, the PICC started to be utilized in the 1990's and has been extensively used in neonatology, pediatry, intensive care units, oncology and in homecare [2-6]. The use of PICC has been steadily increasing every year in neonate intensive care units, being more and more utilized as a device of choice for the longterm intravenous therapy in neonatology $[7,8]$. In neonates, the peripheral venipuncture is performed with a very sensitive technique, which must be performed by properly trained and qualified professionals [9]. For such assistance, there are in the market different types of peripheral devices, with the more utilized being Scalp type needle-catheters, flexible catheters type Abocath and the peripheral-insertion central catheters (PICC).

The newborn subjected to insertion of PICC devices are, mostly, preterm infants of low weight at birth that need those devices to ensure their growth and development, since the organs associated to suction and nutrition are not yet fully developed. The insertion of PICC is a highly complex technical procedure that requires specific skills and knowledge [10]. According to the Intravenous Nurses Society (INS) - Brazil, such procedure is to be performed exclusively by nurses and medical doctors, provided they attended a training course that includes theoretical and practical contents related to the insertion, maintenance and removal of the catheter, indications and contraindications for the use of the device and methods for verifying the insertion, in order to ensure the quality of the procedure and the well-being of the patient [11]. The PICC is a reliable device for the many different types of intravenous infusions, which are necessary both in hospital and homecare environments, since many of the patients complete their healthcare therapy in household [12,13]. However, the PICC possess the disadvantage of restraining the movements when the catheter is inserted in the antecubital fossa, on one hand because fixation may be carried out improperly and, on the other hand, due to the need of daily care to maintain catheter patency, i.e. free from any obstruction, with free passage for the infusions [14]. The main complications after insertion of the PICC are: a) phlebitis, b) cellulitis, c) systemic infection, d) fracture of the catheter with potential embolism, e) catheter occlusion, f) thrombosis, and g) migration of the catheter $[15,16]$.

Since the PICC catheter is widely used in intensive care units, it becomes necessary not just a risk management in manufacturing these catheters, so that complications to the patients are minimized, but also a rigorous physical-chemical control, according to the tests advocated by Brazilian standards ABNT NBR ISO 10555-1:2003 [17] and ISO 10555-3:2003 [18]. In this work, tests were performed on catheters manufactured by a Brazilian industry (Sorocaba SP, Brazil), by using catheters in two distinct phases of the production process, viz. a) in the initial stage, i.e., using only extruded catheters before they have gone through the process of painting and cleaning, and $b$ ) in the finished product, after completion of all the steps involved in manufacturing, including sterilization. These tests were performed according to the requirements advocated by standards ISO 10555-1:2003 and ISO 10555-3:2003, with the aim of investigating whether such standards correctly describe the tests, i.e., whether they were formulated with sufficient clarity so as to allow experimenters to reproduce them unequivocally and without doubts, aiming at ensuring the quality and reliability of all prod- 
ucts encompassed within the scope of such standards.

\section{MATERIALS AND METHODS}

\subsection{Materials}

The imported catheters utilized in the comparative tests were acquired from Becton, Dickinson and Company (BD) (New Jersey, USA).

\subsection{Analytical equipment}

All PICC diameters were determined using a digital caliper rule from Digimess (model 100.179A, São Paulo $\mathrm{SP}$, Brazil). Radiopacity tests were carried out using an x-ray emitting device from VMI (model VMICompacto Plus-125KV, Lagoa Santa MG, Brazil). The semi-analytical scale used was from Acculab (model VI-200, Bradford, USA), with a maximum capacity of $200 \mathrm{~g}$ and accuracy of $\pm 0.01 \mathrm{~g}$. The fluid leakage tests were performed using an inflation syringe with gauge from Scitech (model 105336, Goiania GO, Brazil). The strength to rupture (tensile strength) was measured using a transducer from PASCO (model CI-6537, Roseville, USA) [19] with the ability to measure strain forces up to $\pm 50 \mathrm{~N}$ with a resolution of $0.1 \mathrm{~N}$, with data acquisition made by an analog-digital converter (ADC) also from PASCO (model Science Workshop® 750) [20]. The software for data processing was also from PASCO (DataStudio 1.9.8r10) [21].

\subsection{Experimental procedures}

The PICC catheters are usually made of polyurethane or silicone. Polyurethane is a thermoplastic polymer, being widely used in the production of catheters, and having as major characteristics the resistance, hardness, moldability, biostability, and low thrombogenicity. Silicone presents thermostability, high resistance to folding, low thrombogenicity, low bacterial adherence, and very high biocompatibility. The size of the PICC currently available on the market vary according to the manufacturer. The tests performed were carried out at LAFINAU - Laboratory of Applied Nuclear Physics of the University of Sorocaba (Sorocaba SP, Brazil). The tests were performed at two distinct moments in the PICC production process: (a) Raw-material (PICC$\mathrm{RM}$ ), catheters considered in the initial phase of the production process, i.e. silicone paste immediately after extrusion, and connected to a nozzle; and (b) Finished product (PICC-FP), catheters considered as finished products (the PICC passed through all production process, including the final sterilization procedure). Each test was carried out using at least three samples $(n=3)$ from a PICC Brazilian producer, for the raw material as well as for the finished product. $50 \mathrm{~cm}$-long PICC made of silicone were used in the tests, with $1.9 \mathrm{Fr}$ diameter (Fr - Charrièrre French scale, utilized to express the caliber of different tubular medical instruments, including probes and catheters, which is equivalent, in $\mathrm{mm}$, to divide by 3 the diameter value in Fr, i.e. $1 \mathrm{Fr}=$ $0.333 \mathrm{~mm}$ ). The aim of the study was to evaluate if the production process interferes in the physico-chemical characteristics of the catheters in the initial phase (raw-material) and also in the final phase of their production process (finished product). The results gathered in the tests performed in the present research effort were duly compared with those from an international PICC manufacturer. One has also tested catheters made of polyurethane and, in this case, only finished products from a Brazilian manufacturer (Sorocaba SP, Brazil) were used in the tests $(50 \mathrm{~cm}$-long and with diameters of $2.5 \mathrm{Fr})$. Figure 1 displays all the items that integrate a typical PICC kit, produced and available in Brazil.

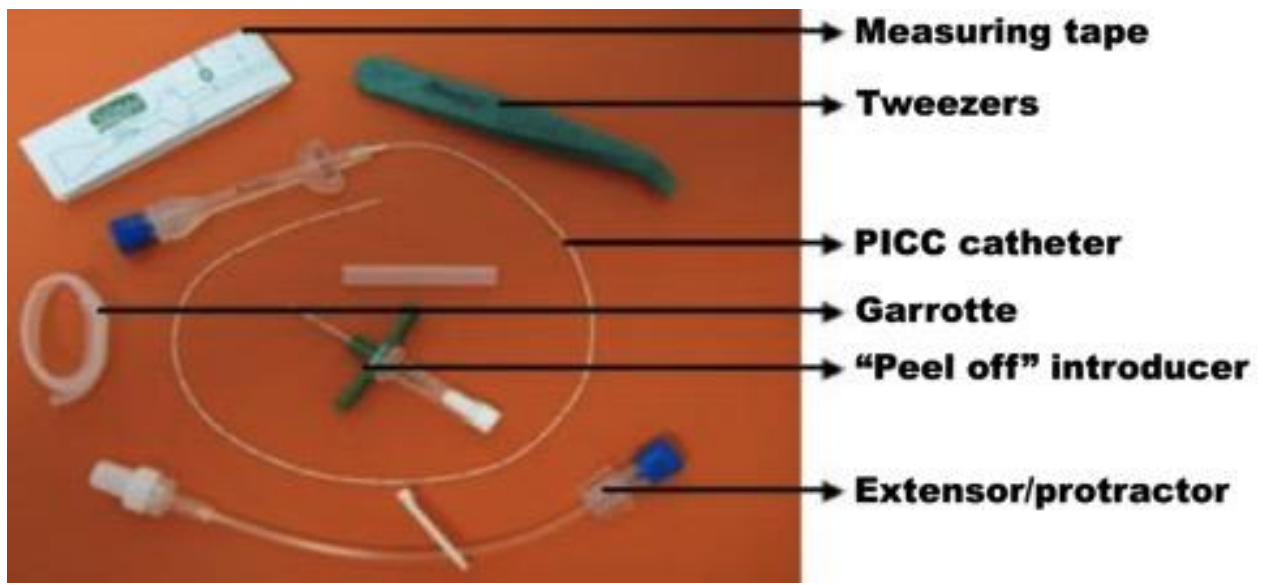

Figure 1: Set of items that accompany the PICC catheter, forming a typical kit of this medical product. 
All tests described in the next sections were performed according to the procedures advocated by the ABNT NBR ISO 10555-1:2003 and ABNT NBR ISO 10555-3:2003 standards.

\subsubsection{Determination of diameter}

For determination of diameter, different points in the PICC tube were measured utilizing a digital caliper rule according to the technique advocated by NBR ISO 10555-1:2003 standard. Determination of the PICC diameter was performed in three different positions along its length aiming at detecting the existence of any oscillations in the PICC diameter, both in the raw material and in the finished product. After performing the measurements, the average and standard deviation were duly calculated.

\subsubsection{Determination of radiopacity}

The radiopacity was determined utilizing the method of attenuation of X-radiation (X-rays) on the materials according to the technique recommended by the NBR ISO 10555-1:2003 standard. The NBR ISO 105553:2003 standard does not describe how should the radiopacity test be performed, but only states that the PICC should be radio-detectable. It is understood that this is not enough to perform the radiopacity test, since the voltage that will be used in the x-ray equipment, as well as the current intensity and exposure time are key factors in the analysis of radiopacity which cannot be neglected. The aforementioned standard also does not specify whether one should cover the catheters with some type of absorbent material (phantom, i.e. a tissue simulator) that simulates the absorption of radiation by the body region of the neonate where the catheter is inserted. According to the Journal of Science and Letters of Ribeirão Preto (São Paulo, SP, Brazil), phantoms (tissue simulators) are generally used in radiodiagnostic centres, being defined by ICRU 48 [22] and ICRP 26 [23] as structures containing one or more equivalent tissues, i.e. any object that simulates a body or tissue with their respective physical and chemical properties, presenting properties of radiation attenuation close to those of the simulated tissue, which depend primarily on the chemical composition of the materials utilized as well as on the energy range applied on each procedure [24].

Essentially, there exist three types of phantoms, viz. (i) body phantom, or anthropomorphic, which is assembled in the shape of a human body or a part of it, generally composed of several substitute materials where each one simulates a given tissue of the body (soft, bone, pulmonary, etc.); (ii) homogeneous phantom, which is composed by only one type of material and has the shape of a cube, generally used as standard object, aiming at comparing irradiations under pre-established conditions in the laboratory; and (iii) bolus phantom, which is a substitute tissue, placed on the part of the body being irradiated, so as to provide a larger scattering and attenuation of the radiation beam [25]. On account of the diversity of radiation types and forms of treatments used in the centers of modern radiotherapy, a large amount of simulating materials in the form of solids, liquids and gels simulating various body tissues, are required [24]. According to Robert Kienbock, in 1906 [26], in what was considered the first study ever on substitute tissues, one aluminum sheet $1 \mathrm{~mm}$ thick is equivalent, in terms of absorption, to a layer of muscle or water $1 \mathrm{~cm}$ thick [26]. In 1913, Theophil Christen Medaille stated that the x-ray beam should be specified in terms of its attenuation in water, introducing also the idea of solid water $[27,28]$. Taking these data into consideration, it was used in the radiopacity test a phantom that simulates radiation absorption by the body of a newborn.

The phantom used was a plastic bag containing inside a layer of water approximately $1.5 \mathrm{~cm}$ thick, which was positioned on top of the PICC. The best image was obtained with the X-ray machine parameterized with a voltage of $40 \mathrm{kV}$, an electric current intensity of $100 \mathrm{~mA}$ and an exposure time of $0.2 \mathrm{~s}$. Two additional tests were carried out, one with a voltage of $44 \mathrm{kV}$, an electric current intensity of $100 \mathrm{~mA}$ and an exposure time of $0.4 \mathrm{~s}$, and another one with a voltage of $40 \mathrm{kV}$, an electric current intensity of $100 \mathrm{~mA}$ and an exposure time of $0.4 \mathrm{~s}$, but, however, the quality of the images obtained with respect to radiopacity was noticeably lower.

\subsubsection{Determination of flow characteristics through the PICC}

The flow characteristics of the PICC tested were evaluated using specific equipment assembled for this purpose according to the technique advocated by the NBR ISO 10555-3:2003 standard. The flow is defined as the amount of liquid that crosses a given transverse section (area) per unit time. Flow determination was carried out utilizing equipment consisting in a constant-level reservoir with a coupled hydrostatic column of $1000 \mathrm{~mm} \pm 5 \mathrm{~mm}$, able to provide a flow of $525 \mathrm{~mL} / \mathrm{min} \pm 25 \mathrm{~mL} / \mathrm{min}$. The device was initially calibrated according to the flow specifications inscribed in the aforementioned standard of $525 \mathrm{~mL} / \mathrm{min}$, and duly tested so as to guarantee that the different measurements were kept within the deviation limits allowed in the aforementioned standard of $25 \mathrm{~mL} / \mathrm{min}$. Once calibrated, the equipment was coupled to the PICC and the water flow through the catheter was measured. The water exiting the catheter was collected in a pre-tarred container (on a semi-analytical scale) in order to obtain the water volume by using the definition of density. 
The water exiting the catheter was collected during a time period of $5 \mathrm{~min}$ at each determination, and least three determinations were performed for each catheter analyzed. With the data gathered, simple flow averages were calculated together with their associated standard deviations. The measurements were normalized to a flow time of $1 \mathrm{~min}$. Figure 2 shows a photograph of the setup utilized to determine the water flow through the PICCs, according to the recommendations advocated by the ISO 10555-3:2003 standard.

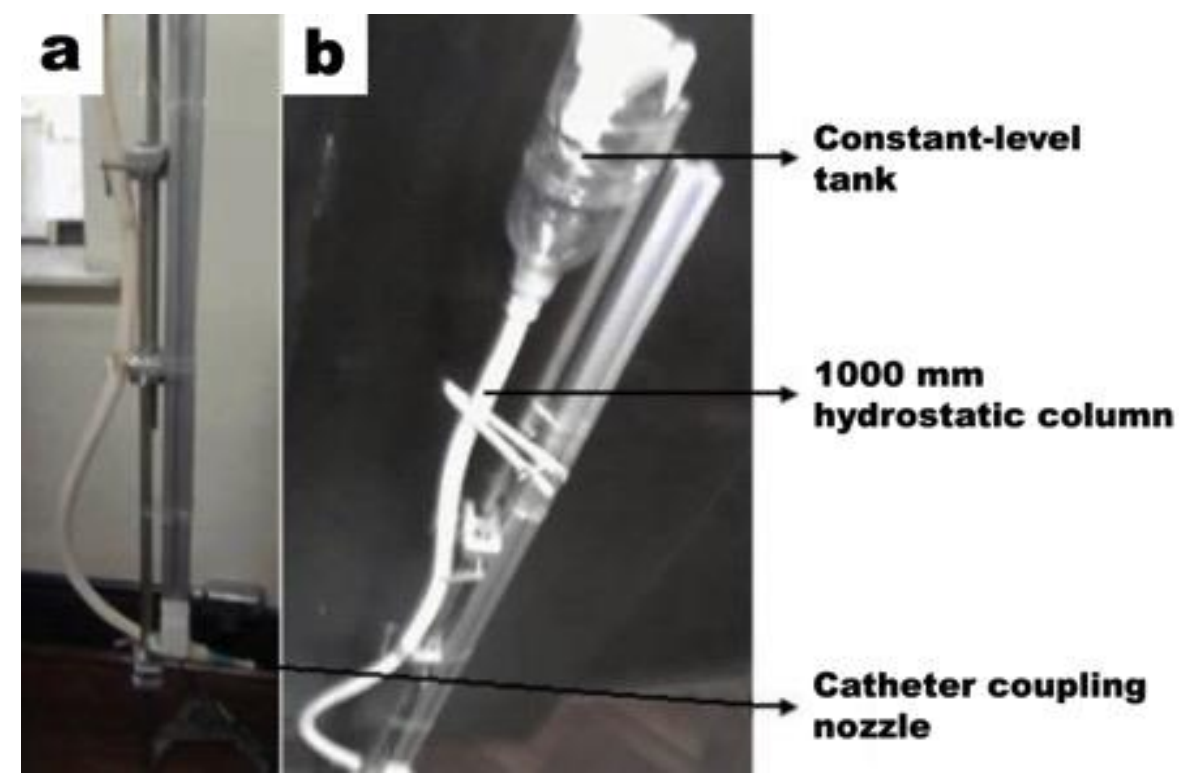

Figure 2: Photographs of the setup utilized to determine the flow rate through the PICC catheters: (a) nozzle where the catheter was connected to obtention of the flow, (b) hydrostatic column and water tank.

\subsubsection{Evaluation of fluid leakage under pressure}

For this evaluation, a specific device was produced according to the technique advocated by the NBR ISO 10555-1:2003 standard. The procedure followed consisted in filling an inflation syringe with deionized water and expel any air that would eventually be in its interior. Subsequently, one adjusted the water volume in the graduated syringe to its nominal capacity. The PICC sample to be tested was duly sealed as close as possible to the distal end, using a flow reducer. The device was then positioned so that the axis of the connection between the syringe and the catheter stayed in the horizontal position. One then applied an axial force to the syringe so that a pressure of 3 atm was reached by the action of the piston, maintaining such applied pressure for a minimum of $30 \mathrm{~s}$. Following this period of time, the leakage of liquid (if any, revealed by the appearance of water droplets) in the barrel assembly and in the catheter tube was duly examined. The formation (if any) of one or more water droplets was counted and reported as leaking. The fluid leakage test was performed using an inflation syringe with gauge, as shown in Figure 3.

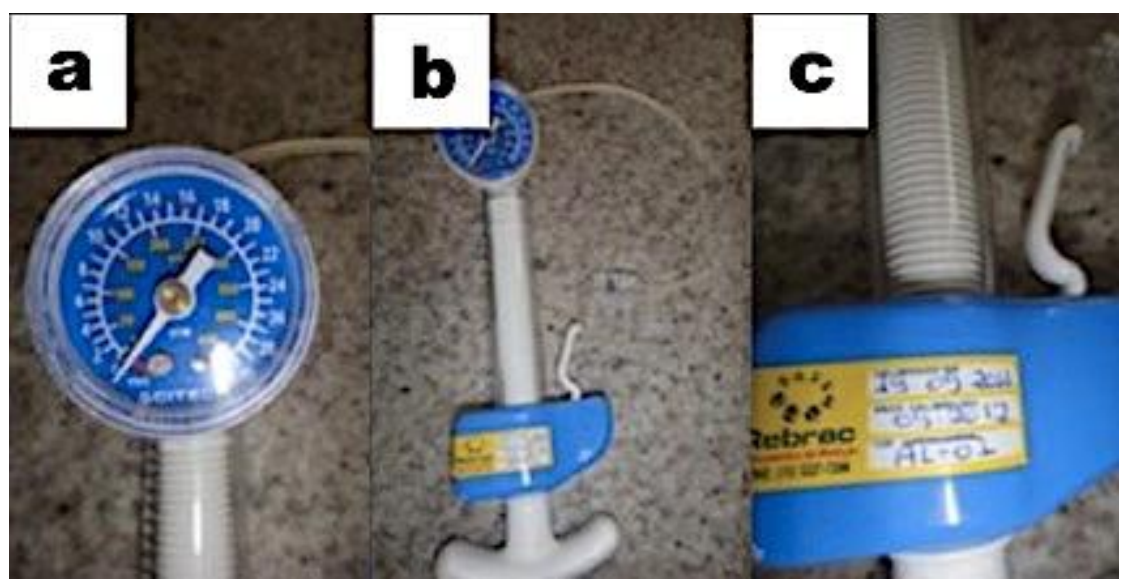

Figure 3: Inflation syringe: (a) Gauge, (b) Front view of the inflation syringe, (c) Calibration certificate. 


\subsubsection{Air leak in the suction cannon assembly}

Evaluation or air leakage in the suction cannon assembly was carried out utilizing specific equipment for this purpose, according to a technique advocated by the NBR ISO 15355-1:2003 standard. The principle of this test consists in engaging the catheter cannon tube, through the male connector, to a $10-\mathrm{mL}$ syringe partially filled without the stem. By pulling the plunger, a negative pressure is applied to the cannon tube-connector interface. One then inspects the formation of air bubbles inside the syringe. The procedure consisted in connecting the mounting reference to the syringe via the connector, closing all valves that were open during aspiration, fill the $10-\mathrm{mL}$ syringe through the PICC sample with a volume of water greater than $25 \%$ of the capacity of the graduated syringe, avoiding to wet the joints between the cannon tube and the reference assembly, and expelling the air from the equipment except for small bubbles. The volume of water in the syringe was then adjusted to $25 \%$ of its graduated capacity. The test sample was then blocked and, with the tip of the syringe oriented downwards, the stem was pulled up to the maximum of its graduated capacity. The stem was hold in that position for 15 seconds, and the water in the syringe duly examined for the presence of any bubbles, ignoring any bubbles formed within the first 5 seconds of the assay. The PICC sample was blocked immediately below the connector, at the beginning of the catheter tube.

\subsubsection{Strength to rupture}

These tests were performed using specific equipment built for this purpose, according to the technique advocated by the NBR ISO 10555-1:2003 standard. The principle of this assay is that the catheter test samples are chosen so that each tubular portion, each junction between cannon tube or connector, and the junction between the tubular portions are all assayed. A force is then applied to each test sample until the tube breaks or the joint separates part. The procedure utilized consisted in mounting the PICC according to the instructions from the manufacturer, and fixing the PICC to the test rig. A suitable holder was utilized, preventing any deformation of the cannon or the connector. One then measured the length of the test sample, that is, the distance between the equipment claw for the tensile test or the distance between the cannon or connector and the claw, and the other end of the PICC sample was fixed as appropriate. A traction force was then applied at a rate of $20 \mathrm{~mm} / \mathrm{min} / \mathrm{mm}$ to the sample, until it separated into two or more parts. The amount of force applied was registered, at which the separation occurred, being recorded as the strength to rupture. Figure 4 shows the equipment built specifically to perform the rupture tests. In Figure $4 \mathrm{a}$, one can see the motorized system responsible to produce the traction of the catheter, while Figure $4 \mathrm{~b}$ depicts the transducer responsible for measuring the force.

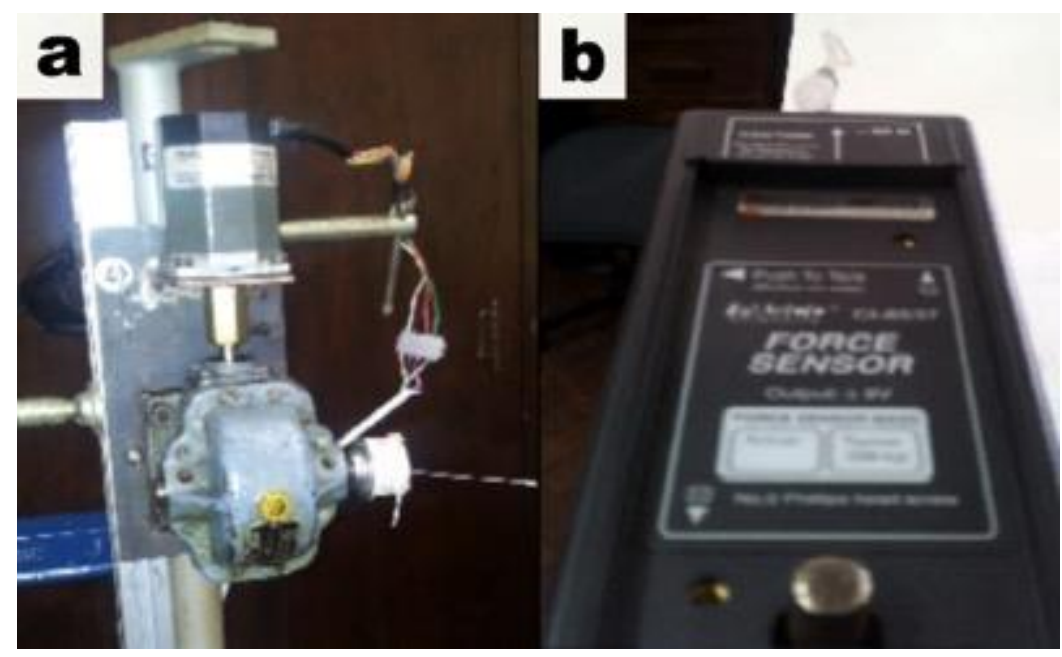

Figure 4: Equipment utilized to perform the tests of strength to rupture: (a) motor system responsible for the traction of the sample, (b) transducer responsible for measuring the force applied on the catheter.

To measure the strength to rupture (tensile strength), a transducer from PASCO was used [19], model CI-6537, with the ability to measure strain forces up to $\pm 50 \mathrm{~N}$ with a resolution of $0.1 \mathrm{~N}$. The data was acquired using an analog-digital converter (ADC) from Pasco, model Science Workshop® 750 [20], and further processed using specific software also provided by PASCO (Data Studio 1.9.8r10) [21]. According to the standard used as reference, the PICC must meet the following minimum values for the traction force to rupture: (i) catheters with diameters in the range $0.55 \mathrm{~mm} \leq \mathrm{d}<0.75 \mathrm{~mm}$ should support at least $3 \mathrm{~N}$, (ii) catheters with diameters in the range $0.75 \mathrm{~mm} \leq \mathrm{d}<1.15 \mathrm{~mm}$ should support at least $5 \mathrm{~N}$, (iii) catheters with di- 
ameters in the range $1.15 \mathrm{~mm} \leq \mathrm{d}<1.85 \mathrm{~mm}$ should support at least $10 \mathrm{~N}$, and (iv) catheters with diameters $\mathrm{d}$ $\geq 1.85 \mathrm{~mm}$ should support at least $15 \mathrm{~N}$ of force before breaking. Figure 5 shows, in a schematic fashion, the setup utilized to perform the traction tests, comprising a stepper motor, a nylon thread, a PICC to be tested, a force sensor, an analog-to-digital converter, and a computer.

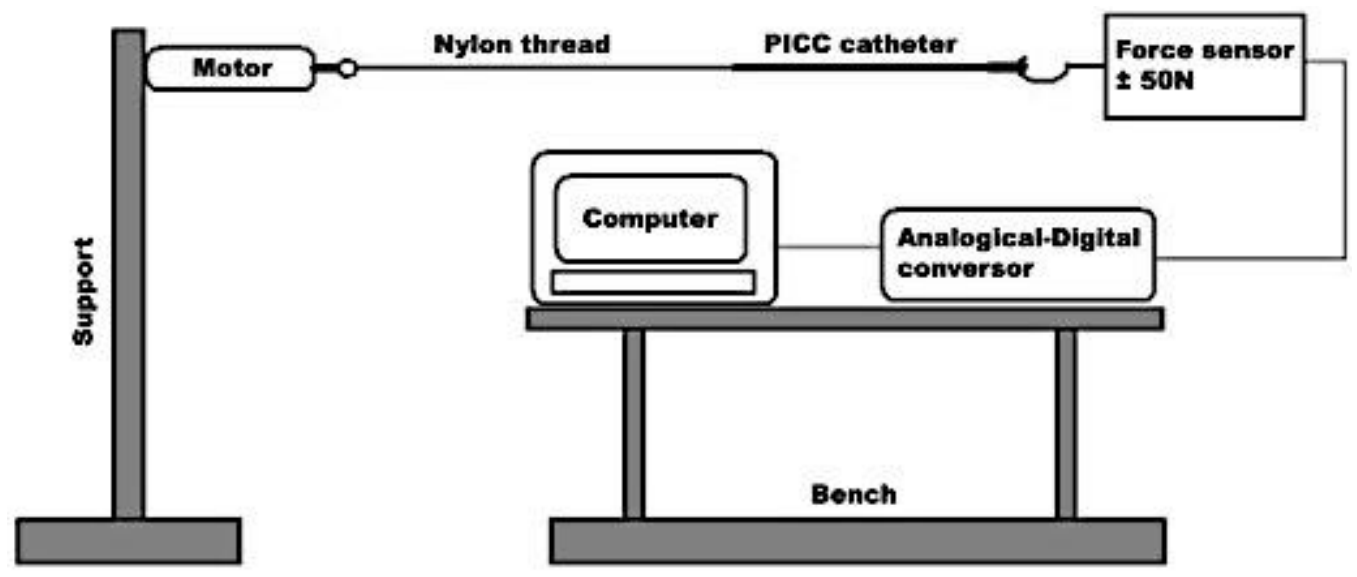

Figure 5: Schematic setup of the assembly utilized to perform the traction tests.

\section{RESULTS AND DISCUSSION}

In this section, the results of all the physical tests performed to the PICC according to the prescriptions advocated by the ABNT NBR ISO 10555-1:2003 and ISO 10555-3:2003 standards are thoroughly displayed and analyzed. Furthermore, one discusses the problems encountered and the solutions proposed to perform the tests, and conclude whether or not the catheters tested meet those standards.

\subsection{Determination of PICC diameters}

The results obtained in the determination of PICC diameters resulted in a value of 1.9 Fr for those catheters made of silicone (Brazilian product, raw material) considering as value the average of all measurements performed and associated standard deviation of $0.638 \mathrm{~mm} \pm 0.006 \mathrm{~mm}$. According to the standards, the PICC diameter can vary $0.05 \mathrm{~mm}$, hence the raw material of the PICC lot analyzed is in agreement with the standard specifications. For the finished product, the average value encountered for the diameter of silicone PICC catheters was now of $0.643 \mathrm{~mm} \pm 0.006 \mathrm{~mm}$. The average diameter of the finished PICC was also according to the standard specifications. Comparing the results obtained for the average diameters of both the raw material and the finished product, one notices that there was no difference, allowing concluding that the manufacturing process does not introduce changes in the diameter of the PICC.

\subsection{Determination of radiopacity}

In Figure 6, a radiographic image is displayed pertaining to the PICC catheters made of silicone used to perform these tests. In the same Figure, radiographic images of the set of Brazilian PICC identified as raw material, of the same set of PICC but now as a finished product, and for the purpose of comparison, of a finished silicone PICC catheter produced by a foreign manufacturer (identified as imported). The image displayed as Figure 6 was obtained using an X-ray emitting equipment and a phantom positioned over the catheters, according to the description made in subsection 2.3.2. of the Materials and Methods section. The parameterization utilized in the x-ray emitting equipment was the following: voltage of $40 \mathrm{kV}$, an electric current intensity of $100 \mathrm{~mA}$ and an exposure time of $0.2 \mathrm{~s}$. This was the set of parameters that allowed obtention of the best radiographic image. A close inspection of Figure 6 allows to conclude that all catheters were radiopaque, both those made in Brazil (raw materials and finished PICC) and those imported. 


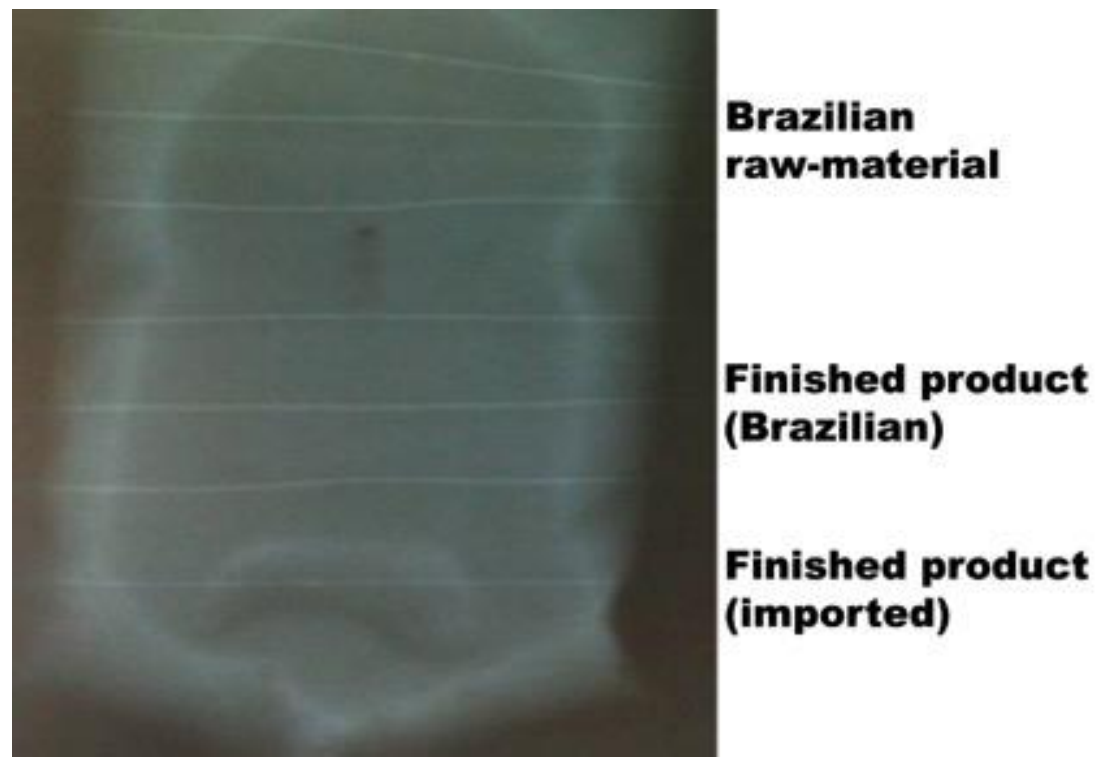

Figure 6: Radiographic image of PICC catheters made of silicone, obtained with an x-ray machine with the following parameterization: voltage of $40 \mathrm{kV}$, exposure time $\mathrm{t}=0.2 \mathrm{~s}$, and electric current intensity $100 \mathrm{~mA}$.

Through a visual inspection of the radiographic image displayed as Figure 6, one can say that there were no significative differences between raw material and finished product. When comparing the PICC (raw material and finished product) produced in Brazil with the imported one, also no significative differences whatsoever could be observed. In what concerns radiopacity, one may conclude that both the silicone PICC (raw material and finished product) made in Brazil and the imported silicone PICC were all radiopaque, thus attending to the requirements of the standard. From the visual inspection made to the radiographic image displayed as Figure 6, one can also conclude that the manufacturing process does not change the radiopacity of the catheters.

\subsection{Determination of flow characteristics through the PICC}

The flow rate determined without the catheter coupled at the distal section, according to the standard specifications, should be of $525 \mathrm{~mL} / \mathrm{min} \pm 25 \mathrm{~mL} / \mathrm{min}$. The average flow rate obtained under these conditions, after calibration of the setup, was of $523.6 \mathrm{~mL} / \mathrm{min} \pm 4.97 \mathrm{~mL} / \mathrm{min}$. In these tests one used silicone PICC catheters, with 1.9 Fr diameter and 50-cm long, mono-lumen (single hole), from a Brazilian manufacturer. The average values obtained for the flow rate and their associated standard deviations, for the raw material and finished product, were $0.051 \mathrm{~mL} / \mathrm{min} \pm 0.003 \mathrm{~mL} / \mathrm{min}$ and $0.054 \mathrm{~mL} / \mathrm{min} \pm 0.002 \mathrm{~mL} / \mathrm{min}$, respectively. The nominal value for the flow rate through the catheter must be specified by the manufacturer, and may vary depending on the manufacturer. The results obtained clearly show that there were no differences whatsoever in the flow rate of the raw material when compared with that of the finished PICC product.

\subsection{Evaluation of fluid leakage under pressure}

The catheters used in these trials were the silicone PICC with 1.9 Fr diameter (50-cm long, mono-lumen, from a Brazilian manufacturer). The aim of these tests was to identify any leakages from the catheters. The results obtained for all catheters tested did not show the presence of any leakage whatsoever, both for the raw materials and finished PICC. One can conclude that both raw materials and finished PICC products fully passed the tests, i.e., there were no leakages in the cannons and in the catheter tubes, in agreement with the standards. Additionally, one can also conclude that the manufacturing process did not promote any changes whatsoever in the characteristics of the catheters in what concerns the presence of any fluid leakage under pressure.

\subsection{Air leak in the suction cannon assembly}

The catheters used in these trials were the silicone PICC with 1.9 Fr diameter (50-cm long, mono-lumen, from a Brazilian manufacturer). In these tests the goal was to identify if there was any air leak in the PICC. The results of the tests were negative for both raw materials and finished PICC products, thus providing information that the catheters tested were in agreement with the standard requirements, and also that the manufacturing process did not change the characteristics of the catheters. 


\subsection{Determination of the strength to rupture}

The experimental assays aiming at determining the strength (resistance) to rupture of the PICC catheters depends on the length of the catheters. Thus, according to the standard NBR ISO 10555-1:2003, the catheter must be pulled along its length at a constant speed, depending on the length of the catheter. Table 1 shows, for different catheter lengths, which must be the traction speed.

Table 1: Relationship between PICC length and traction speed.

\begin{tabular}{ll}
\hline Catheter length $(\mathbf{m m})$ & Traction speed $(\mathbf{m m} / \mathbf{m i n})$ \\
\hline 10 & 200 \\
20 & 400 \\
25 & 500 \\
\hline
\end{tabular}

Source: NBR ISO 10555-1:2003 standard

The catheters used in these trials were the silicone PICC with 1.9 Fr diameter $(50-\mathrm{cm}$ long, monolumen, from a Brazilian manufacturer). The point of application of force, in each tubular portion of catheters, that is, the distance between the equipment claw for the tensile test and the other end of the PICC sample, used in these tests, was $250-\mathrm{mm}$ long, thus, the constant longitudinal traction speed imparted according to the standard (see Table 1) was of $5000 \mathrm{~mm} / \mathrm{min}$. The results from the rupture tests performed on the raw material are displayed in Table 2 .

Table 2: Results obtained for the force to rupture, in the tests performed to the raw-material.

\begin{tabular}{ll}
\hline Sample & Force to rupture $(\mathbf{N})$ \\
\hline 1 & 2.26 \\
2 & 2.16 \\
3 & 2.04 \\
4 & 2.38 \\
5 & 2.06 \\
\hline
\end{tabular}

Figure 7 shows the plot utilized to determine the values of the strength to rupture exhibited in Table 2. The plot in Figure 7 was built utilizing the data analysis software provided by PASCO (Data Studio 1.9.8r10) [21]. At the exact instant when rupture occurs, the curve exhibits an inflection point, i.e., the values of the force as a function of time stop growing (negatively) abruptly. The force values in the plot of Figure 7 appear negative simply because the transducer utilized provided positive values when tractioned in one direction and negative values when tractioned in the opposite direction. The direction utilized in these experimental trials was that where the transducer provided negative values for the force applied. 


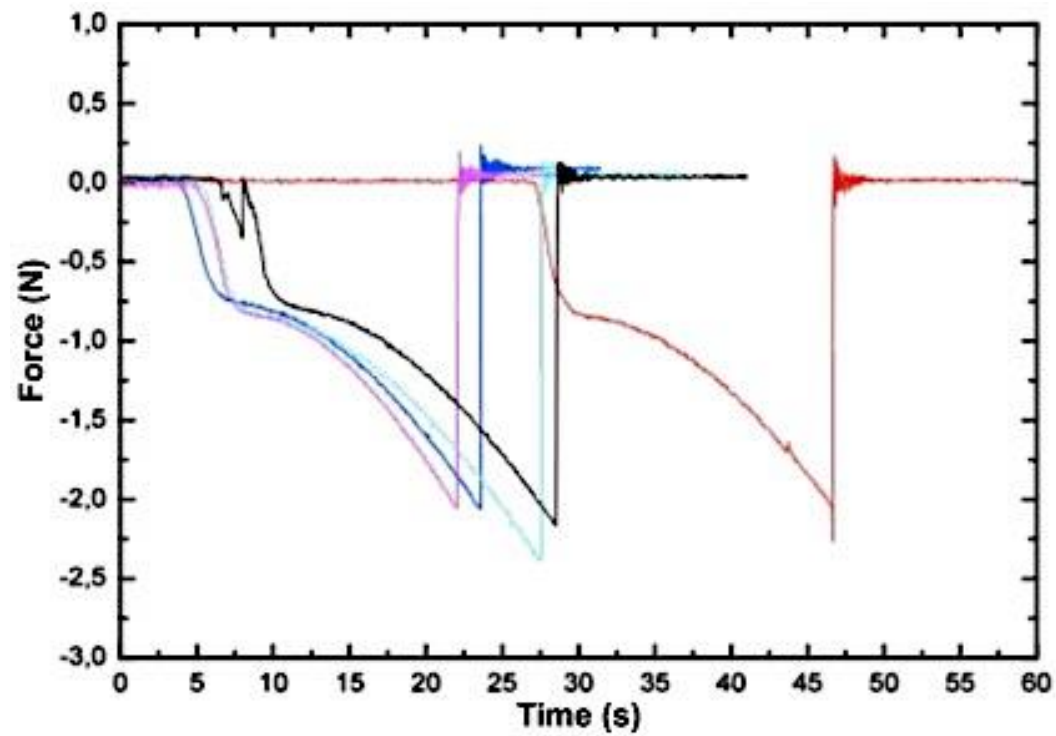

Figure 7: Plot of the applied force as a function of time, for the different samples of raw-material of silicone catheters, whose values of the strength to rupture are displayed in Table 2: sample 1 - red line, sample 2 black line, sample 3 - pink line, sample 4 - light blue line, and sample 5 - dark blue line.

Table 3 displays the results obtained in the rupture tests performed in the same type of catheter, but now as a finished PICC product. In Figure 8, one can see the plot obtained for the applied force as a function of time for the finished PICC product.

Table 3: Results obtained for the force to rupture, in the tests performed to the finished product.

\begin{tabular}{ll}
\hline Sample & Force to rupture $(\mathbf{N})$ \\
\hline 1 & 1.91 \\
2 & 1.56 \\
3 & 1.77 \\
4 & 1.82 \\
\hline
\end{tabular}

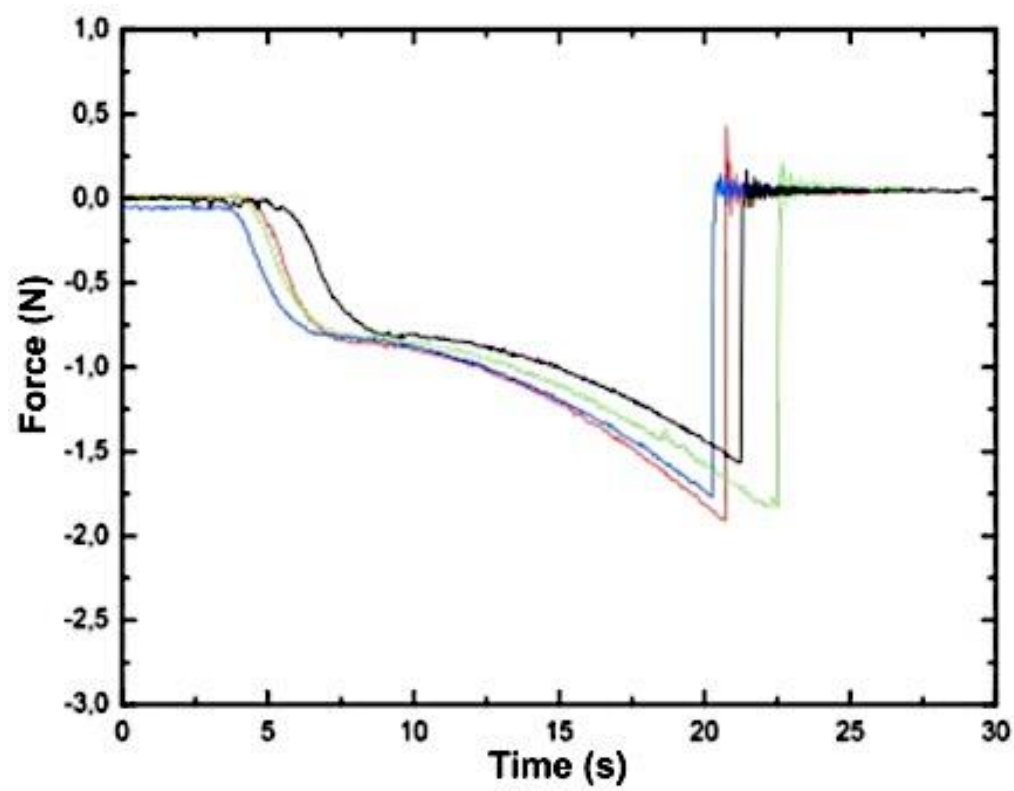

Figure 8: Plot of the applied force as a function of time, for the different samples of finished PICC catheters made of silicone, whose values of the strength to rupture are displayed in Table 3: sample 1 - red line, sample 2 - black line, sample 3 - dark blue line, and sample 4 - green line. 
By calculating the average value and associated standard deviation for the strength to rupture of the raw material $(2.18 \mathrm{~N} \pm 0.14 \mathrm{~N})$ and comparing with the average value obtained for the finished PICC product $(1.76 \mathrm{~N} \pm 0.15 \mathrm{~N})$, allows to observe that the finished PICC catheters presented a lower mechanical resistance, breaking up for smaller values of tensile forces than those supported by the raw materials. This observation allows us to state that there were in fact some changes produced in the catheters probably associated with the manufacturing process. According to the standard NBR ISO 10555-1:2003, those catheters with 1.9 Fr diameter $(1 \mathrm{Fr}=0.333 \mathrm{~mm})$ must withstand a minimum force of $3 \mathrm{~N}$ before breaking up. Table 4 displays some values of the minimum force to withstand before rupture, that catheters must resist, as a function of the diameter of the smaller tubular segment of the PICC sample, according to the standard NBR ISO 10555-1:2003.

Table 4: Relationship between the external diameter of the catheter and the minimum force to rupture.

\begin{tabular}{ll}
\hline External diameter of PICC $(\mathbf{m m})$ & Minimum force to rupture $(\mathbf{N})$ \\
\hline $0.55 \leq \mathrm{d}<0.75$ & 3 \\
$0.75 \leq \mathrm{d}<1.15$ & 5 \\
$1.15 \leq \mathrm{d}<1.85$ & 10 \\
$\mathrm{~d} \geq 1.85$ & 15 \\
\hline
\end{tabular}

Source: NBR ISO 10555-1:2003 standard

Analyzing the average values obtained for the strength (force) to rupture of the catheters utilized in these tests, both the raw material and the finished PICC product were disapproved because they should withstand a force of at least $3 \mathrm{~N}$ before breaking up. In fact, all samples ruptured before the applied traction force reached that value. The initial goal of the present research effort was not to test imported PICC catheters, but since an imported silicone PICC was available (with 1.9 Fr diameter, 50-cm long, mono-lumen) with the same exact specifications of the Brazilian catheters utilized in the experimental trials, one decided to test it for the strength to rupture, just for the sake of having another element for discussion and comparison of the results, aiming at producing suggestions for further analyses of the Brazilian PICC catheters. The imported sample utilized in the test was 250-mm long and thus, by following the standard, one applied a traction speed of $5000 \mathrm{~mm} / \mathrm{min}$. The strength to rupture (force until breaking up) obtained for the imported PICC was 0.69 $\mathrm{N} \pm 0.1 \mathrm{~N}$, which shows that, at least in the case of the sample tested, the imported catheter not only did not meet the standards but also presented a breaking strength far below that recommended in the Brazilian standard. Since the standard, in the case of the breaking strength, only relates the value of the external diameter of the PICC tubular section with the minimum traction force that it should withstand, not correlating this relationship with the type of material of which the PICC is made of, one decided, for comparison purposes, to test a finished PICC product not made of silicone. One chose, for this purpose, an umbilical catheter made of polyurethane, with 2.5 Fr diameter, mono-lumen, also from a Brazilian manufacturer. The length of the polyurethane PICC was of $250 \mathrm{~mm}$, and therefore the traction speed used (according to the standard) should be of $5000 \mathrm{~mm} / \mathrm{min}$. Table 5 displays the results obtained for the rupture tests performed with this catheter, and in Figure 9 one can see the plot of the applied (traction) force as a function of time, for the umbilical catheters made of polyurethane.

Table 5: Results obtained for the force to rupture, in the tests performed to the finished product, for PICC made of polyurethane (diameter of $2.5 \mathrm{Fr}$, mono-lumen, Brazilian-made).

\begin{tabular}{ll}
\hline Sample & Force to rupture $(\mathbf{N})$ \\
\hline 1 & 14.61 \\
2 & 10.80 \\
3 & 14.35 \\
4 & 15.24 \\
5 & 14.49 \\
\hline
\end{tabular}




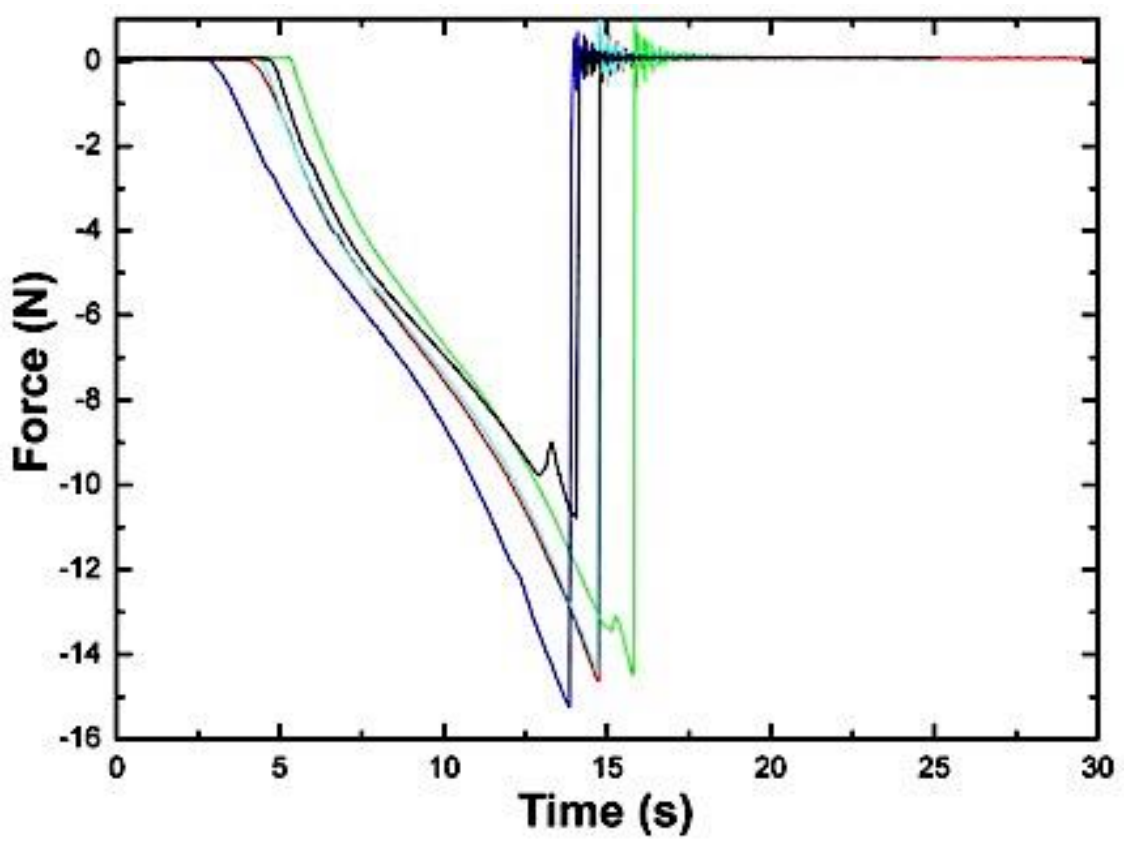

Figure 9: Plot of the applied force as a function of time, for the different samples of finished PICC catheters made of polyurethane, whose values of the strength to rupture are displayed in Table 5: sample 1- red line, sample 2 - black line, sample 3 - light blue line, sample 4 - Dark blue line, and sample 5 - green line. The different colors in the plot indicate distinct catheters.

For PICC catheters with external diameters of $2.5 \mathrm{Fr}(0.833 \mathrm{~mm})$, the standard specifies that the minimum traction force until rupture is produced should be $5 \mathrm{~N}$. By calculating the average value for the strength to rupture and associated standard deviation, of the polyurethane catheters, one obtained the result of $13.89 \mathrm{~N}$ $\pm 1.76 \mathrm{~N}$, thus indicating that these catheters are far much more resistant to breaking up than those catheters made of silicone, and that they attend the standard in what concerns resistance to the minimum traction force until rupture is produced. It is not possible to state categorically that the standard is flawed, with regard to the breaking strength, because it does not take into account, in calculating the tensile strength of the material, the material of which the catheter is made of, considering only its outer diameter. The results obtained in the research effort entertained herein clearly indicate that it would be prudent to the standard, with regard to the breaking strength, to correlate not only the outer diameter of the PICC catheter, but also the material which they are made of.

\section{CONCLUSIONS}

By using silicone and polyurethane PICC, one performed the tests advocated by the Brazilian standards ABNT NBR ISO 10555-1:2003 and ABNT NBR ISO 10555-3:2003, aiming at evaluating if the production process of catheters made of silicone induce significative changes in the parameters specified by those standards, when one compares the raw material (i.e., catheters immediately after the extrusion process) and finished PICC catheters (i.e., catheters that went through all the production stages, including painting, cleaning and sterilization).

Considering the results obtained in the tests performed according to the standards, relative to the peripherally-inserted central catheters (PICC) made of silicone, with exception to the test of strength to rupture, one verified that the silicone PICC catheters made in Brazil are in conformity with the standards, both as raw materials and as finished products. More specifically, in the case of Brazilian catheters made of silicone, one can state that the results from the tests aiming at determining the external diameter, radiopacity, flow rate through the catheter, liquid leakage under pressure, and air leakage in the sucking cannon assembly, are not affected by the production process, since similar values were produced for both raw materials and finished PICC products.

The same did not occur, however, with the test used to determine the strength to rupture, which produced different values for both catheters at the beginning of the production process (raw material) and finished PICC catheters, with a small decrease in the traction force needed to produce rupture of the finished PICC catheters. Both situations failed to comply with the standards, since the average values obtained for the strength (force) to rupture, for the raw materials as well as for the finished PICC products stayed below the 
minimum values specified by the standard.

Hence, it would be interesting to investigate what in the production process causes a decrease in the mechanical resistance of the catheters with respect to the strength to rupture. The identification of this mechanism would indicate the need to change either the composition of the catheters (raw materials) or the production process. Once the source of these changes is understood, there may be also a need for a revision of the standards. The failure to meet the standards, in catheters from a Brazilian producer, led to examination of an identical catheter but of a foreign manufacturer.

The results from the rupture tests performed in the imported catheter also did not meet the specifications inscribed in the Brazilian standard. However, these results should be analyzed with restrictions, since only one sample of foreign catheter was available for testing and therefore, from a statistical point of view, one cannot draw any conclusion. The results obtained with the imported product could, however, be used as a suggestion for future work in comparative testing between Brazilian-made and imported PICC catheters.

The standards that address the rupture test do not have any details on the type of material of which the catheters are made of. Taking this into consideration, one decided to test Brazilian catheters made of polyurethane, in order to verify if these catheters were also not in accordance with the standards in relation to the rupture test. The tests were carried out with umbilical catheters made of polyurethane with 2.5 Fr diameter values. One found values for the strength to rupture higher than those found in catheters made of silicone, thus indicating a higher tensile strength in such catheters. In fact, some catheters made of polyurethane supported a tensile force before breaking up, of up to two times greater than the standards established. This result indicates that the standards should consider the material of which the catheter is made of, since materials with different chemical composition will hardly present the same mechanical properties, thus supporting the need for revision of the Brazilian standards in what concerns the strength to rupture. We must consider that, regardless of the material, the force requested will be the same, so specifying only the tensile strength can bring more failure problems in the PICC. The importance of this test is due to the fact that the incidence of rupture of the PICC catheters in hospitals is around $4 \%$ to $5 \%$ in neonates which, adding to the fact of being premature babies, greatly increase the risk of complications that can lead to death. Nor could we not say that, when a catheter hardly breaks, the problem is referred either to the manufacturing process or the type of material used, as it is easier to blame the professionals responsible for handling these catheters than to demand the certificate of compliance from the manufacturer, certifying that the catheter lot used was in accordance with the technical specifications contained in the standards.

With regard to the radiopacity tests, it can be stated that the standards are flawed, since they only indicate that the catheter must be radiodetectable, not describing how should the test be performed. As discussed in the text above, one can parameterize the x-ray machine using different values for the voltage, current intensity and exposure time, that will be used in the radiography, thereby generating different images that are impossible to be compared between them. The Brazilian standard governing this item also does not tell whether one needs to use some kind of phantom placed over the catheters in order to simulate the radiation absorption by the human body. It was decided, therefore, to use a phantom which, according to our vision, served well the purpose of simulating the human tissue situated above the catheter, in the case of a neonate.

It is noteworthy that the attenuation experienced by a beam of $\mathrm{x}$-rays when crossing the soft tissues of a newborn child is very similar to the absorption that the $\mathrm{x}$-ray experiment when they pass through the bag (phantom) containing water. By using the parameterization voltage of $40 \mathrm{kV}$, current intensity of $100 \mathrm{~mA}$, an exposure time of $0.2 \mathrm{~s}$ and the phantom described in the text, it can be stated that the PICC catheters tested were radio-detectable. In addition, studies reported in the specialty literature clearly show that the radiopacity test is of paramount importance, since the incidence of poor positioning of the PICC catheters lies between 5\%-62\% [8] and, if we add to this figure errors arising from problems of visualization of the catheter tip in the radiographic image, for sure the neonates will be subjected to risks that could be otherwise avoided, just because the standards are flawed in this regard.

Furthermore, it was shown in the research effort entertained herein that with a little creativity and limited resources it was possible to assemble much of the equipment needed to accomplish the tests recommended in the Brazilian standards ISO 10555-1:2003 and ISO 10555-3:2003.

Finally, it must be emphasized that the current research effort was directed towards an area underexplored since it involves the production process of PICC catheters. The scientific literature abounds in clinical studies on the use of PICC, being generally focused on their use and complications arising from this use [8], but not in those involved with materials and production processes. In this sense, the findings reported in the current research effort may be indicative for a review of the Brazilian standards that deal with the technical specifications and compliances that PICC catheters must follow. 


\section{ACKNOWLEDGEMENTS}

Project funding by Fundação de Amparo à Pesquisa do Estado de São Paulo (FAPESP, São Paulo, Brazil) (FAPESP Refs. No. 2012/15651-4, 2013/03181-6, 2016/08884-3 (Project PneumoPhageColor), 2016/122344 (Project TransAppIL)), is hereby gratefully acknowledged. Funding to Victor M. Balcão by FAPESP (São Paulo, Brazil) in the form of a BPE fellowship (FAPESP Ref. No. 2018/05522-9 (Project PsaPhageKill)) is hereby gratefully acknowledged. This work also received support from CNPq, National Council for Scientific and Technological Development - Brazil, in the form of Research Productivity (PQ) fellowships granted to Victor M. Balcão (Refs. No. 306113/2014-7 and 308208/2017-0) and Marco Chaud (Ref. No. 309598/2014-1). The authors have no conflicts of interest whatsoever to declare.

\section{BIBLIOGRAPHY}

[1] PHILPOT, P., GRIFFITHS, V., "The peripherally inserted central catheter", Nurs. Stand., v. 17, n. 44, pp. 39-49, 2003.

[2] RACADIO, J. M., DOELLMAN, D. A., JOHNSON, N. D., et al., "Pediatric peripherally inserted central catheters: complication rates related to catheter tip location", Pediatrics, v. 107, n. 2, pp. E28, 2001.

[3] TOMA, E., Avaliação do uso do PICC - cateter central de inserção periférica em recém-nascidos, Ph.D: Dissertation, UNIVERSIDADE DE SÃO PAULO, USP, 177pp., 2004.

[4] TAWIL, K. A., ELDEMERDASH, A., HATHLOL, K. A., et al., "Peripherally inserted central venous catheters in newborn infants: malpositioning and spontaneous correction of catheter tips", Am. J. Perinatol., v. 23, n. 1, pp. 37-40, 2006.

[5] RODRIGUES, Z. S., CHAVES, E. M. C., CARDOSO, M. V. L. M. L., "Action of the nurse with peripherally inserted central catheter in the infant newborn", Rev. Bras. Enferm., v. 59, n. 5, pp. 626-629, 2006.

[6] VENDRAMIM, P., PEDREIRA, M. L. G., PETERLINI, M. A. S., "Cateteres centrais de inserção periférica em crianças de hospitais do município de São Paulo", Revista Gaúcha de Enfermagem, v. 28, n. 3, pp. 331-339, 2007.

[7] CHLEBICKI, M. P., TEO, E. K., "Review of peripherally inserted central catheters in the Singapore acute-care hospital”, Singapore Med. J., v. 44, n. 10, pp. 531-535, 2003.

[8] JESUS, V. C., SECOLI, S. R., "Complicações acerca do cateter venoso central de inserção periférica (PICC)", Revista Ciência Cuidado e Saúde, v. 6, n. 2, pp. 252-260, 2007.

[9] CARLSON, K. R., "Correct utilization and management of peripherally inserted central catheters and midline catheters in the alternate care setting", J. Intraven. Nurs., v. 22, pp. 6-46, 1999.

[10] FRICKE, B. L., RACADIO, J. M., DUCKWORTH, T., et al., "Placement of peripherally inserted central catheters without fluoroscopy in children: initial catheter tip position", Radiology, v. 234, n. 3, pp. 887$892,2005$.

[11] SECOLI, S. R., KISHI, H. M., CARRARA, D., "Inserção e manutenção do PICC: aspectos da prática clínica de enfermagem em oncologia”, Prática Hospitalar, v. 7, n. 47, pp 155-162, 2006.

[12] GEDDES, L. A. B., NICHOLS, H. A., "An overview of peripherally inserted central catheters", Adv. Pract. Nurs. J., v. 5, n. 3, pp. 1-9, 2005.

[13] BAIOCCO, G. G., SILVA, J. L. B., "A utilização do cateter central de inserção periférica (CCIP) no ambiente hospitalar", Revista Latino-Americana de Enfermagem, v. 18, n. 6, pp. 1131-1137, 2010.

[14] BISHOP, L., DOUGHERTY, L., BODENHAM, A., et al., "Guidelines on the insertion and management of central venous access devices in adults", Int. J. Lab. Hematol., v. 29, n. 4, pp. 261-278, 2007.

[15] CAMARA, D., "Minimizing risks associated with peripherally inserted central catheter in the NICU", Am. J. Mater. Child. Nurs., v. 26, n. 1, pp. 17-21, 2001.

[16] OGILVIE, J. W., MELIN, M. M., "Unsuccessful peripherally inserted central catheter placement", $J$. Vasc. Interv. Radiol., v. 17, n. 5, pp. 913, 2006.

[17] ABNT (ASSOCIAÇÃO BRASILEIRA DE NORMAS TÉCNICAS) NBR ISO 10555-1: cateter intravascular de uso único, estéril, parte 1: requisitos gerais. Rio de Janeiro, 2003a.

[18] ABNT (ASSOCIAÇÃO BRASILEIRA DE NORMAS TÉCNICAS) NBR ISO 10555-3: cateter intravascular de uso único, estéril, parte 3: cateter venoso central. Rio de Janeiro, 2003b.

[19] PASCO SCIENTIFIC (2013a) Available online: http://www.pasco.com/prodCatalog/CI/CI-6537_force- 
sensor/index.cfm\#overviewTab.

[20] PASCO SCIENTIFIC (2013b) Available online: http://www.pasco.com/prodCatalog/CI/CI-7650_750interface-usb/index.cfm

[21] PASCO SCIENTIFIC (2013c) Available online: http://www.pasco.com/support/downloads/ datastudioupdate.cfm

[22] BETHESDA, M. D., "Phantoms and Computational Models in Therapy, Diagnosis and Protection", International Commission on Radiation and Measurements, Report 48, 1992.

[23] INTERNATIONAL COMMISSION ON RADIOLOGICAL PROTECTION, "Recommendations of the ICRP", Publication 26, Pergamon Press, Oxford, UK, 1977.

[24] MAYLES, P., NAHUM, A., ROSENWALD, J. C., Handbook of Radiotherapy Physics: Theory and Practice, Boca Raton: CRC Press Taylor \& Francis, 1470p, 2007.

[25] BETHESDA, M. D., "Tissue substitutes in radiation dosimetry and measurements", International Commission on Radiation and Measurements, Report 44, 1989.

[26] KIENBOCK, R., "On the Quantimetric Method", Arch. Roentgen Ray, v. 11, pp. 17-20, 1906.

[27] WHITE, D. R., "Tissue substitutes in experimental radiation physics", Medical Physics, v. 5, n. 6, pp. 467-479, 1978.

[28] INTERNATIONAL COMMISSION ON RADIATION UNITS AND MEASUREMENTS, "Tissue Substitutes in Radiation Dosimetry and Measurement", ICRU Report 44, U.S.A., 1989.

\section{ORCID}

Fabiana Cristina Rosa Mitelmão

Salvador Mangini Filho

Marco Vinícius Chaud

Marta Maria Duarte Carvalho Vila

Victor Manuel Cardoso Figueiredo Balcão

José Martins de Oliveira Junior https://orcid.org/0000-0002-4937-8739

https://orcid.org/0000-0001-6313-0302

https://orcid.org/0000-0003-3618-8415

https://orcid.org/0000-0002-0198-7076

https://orcid.org/0000-0003-0772-2834

https://orcid.org/0000-0001-6435-1908 